\title{
Nitrate Transport Rate in the Xylem of Tomato Plants Grafted onto a Vigorous Rootstock
}

\author{
Francisco Albornoz ${ }^{1,2, *} \mathbb{C}$, Alonso G. Pérez-Donoso ${ }^{3}{ }^{\complement}$, Jorge Leigh Urbina ${ }^{1}$, \\ Matías Monasterio $^{1}$, Miguel Gómez ${ }^{1}$ and Úrsula Steinfort ${ }^{1}$ (D) \\ 1 Departamento de Ciencias Vegetales, Facultad de Agronomía e Ingeniería Forestal, Pontificia Universidad \\ Católica de Chile, Avenida Vicuña Mackenna 4860, Macul, Santiago 7820436, Chile; jeleigh@uc.cl (J.L.U.); \\ mlmonasterio@uc.cl (M.M.); mgomezu@uc.cl (M.G.); usteinfo@uc.cl (Ú.S.) \\ 2 Centro UC Desierto de Atacama, Pontificia Universidad Católica de Chile, Avenida Vicuña Mackenna 4860, \\ Macul, Santiago 7820436, Chile \\ 3 Departamento de Fruticultura y Enología, Facultad de Agronomía e Ingeniería Forestal, Pontificia \\ Universidad Católica de Chile, Avenida Vicuña Mackenna 4860, Macul, Santiago 7820436, Chile; \\ agperez@uc.cl \\ * Correspondence: fralbornoz@uc.cl; Tel.: +56-(2)-2354-4111
}

Received: 30 November 2019; Accepted: 24 January 2020; Published: 27 January 2020

\begin{abstract}
Vigorous interspecific rootstocks increase nitrogen $(\mathrm{N})$ uptake in tomato plants but limited information is available on xylem transport rate. Non-grafted and self-grafted tomato plants cv. Attiya and plants grafted onto an interspecific hybrid, Kaiser, were grown under growth chamber conditions and subjected to two light levels, 400 or $800 \mu \mathrm{mol} \mathrm{PAR} \mathrm{m}{ }^{-2} \mathrm{~s}^{-1}$. Plant water uptake, xylem sap $\mathrm{NO}_{3}{ }^{-}$ content, and stem hydraulic conductance $\left(\mathrm{k}_{\mathrm{s}}\right)$ were measured after two weeks of growth. Xylem vessel number and diameter were evaluated in cross-sectional stem cuts and the theoretical xylem hydraulic conductance $\left(\mathrm{k}_{\mathrm{h}}\right)$ was calculated. Only the light level modified the xylem $\mathrm{NO}_{3}{ }^{-}$content. Grafting reduced $\mathrm{k}_{\mathrm{s}}$ by $84 \%$ in comparison to non-grafted plants. The water uptake rate and xylem sap $\mathrm{NO}_{3}{ }^{-}$content were $4.02 \pm 0.66 \mathrm{~g} \mathrm{H}_{2} \mathrm{O} \mathrm{kg}^{-1} \mathrm{DW} \mathrm{h}^{-1}$ and $12.78 \pm 1.16 \mathrm{mM}$, respectively, across all grafting treatments. The rootstock has a higher $\mathrm{k}_{\mathrm{h}}$ because the vessel diameter is $79.3 \pm 14.4 \mu \mathrm{m}$ while in non-grafted plants it is $62.0 \pm 10.1 \mu \mathrm{m}$. Nitrate concentration and transport rate changes accordingly to the plant's growth rate. The vigorous rootstock relies on larger vessels to supply the required amounts of $\mathrm{N}$.
\end{abstract}

Keywords: xylem vessel density; vessel diameter; stem hydraulic conductance; Solanum lycopersicum $\times$ Solanum habrochaites

\section{Introduction}

The practice of grafting plants for horticultural purposes has been commercially in use since the 1920s starting in Asia [1]. The main advantage of joining two genotypes (sometimes two different species) is the tolerance to abiotic and/or biotic stresses of the genotype in the bottom (the rootstock) while preserving the characteristics of the genotype on top (the scion). Current solanaceous breeding programs are mostly targeting the development of material for cultivation under greenhouse conditions, since they promote vigorous growth of the plant which results in increased yields [1].

Vigorous plants require the uptake of higher amounts of all macronutrients including nitrogen $(\mathrm{N})$. Depending on the combination of rootstock and scion, contrasting results have been reported with regards to the concentration of $\mathrm{N}$ in the biomass, resulting in similar [2] or higher [3] contents than in non-grafted plants. Once $\mathrm{N}$ is absorbed by the roots, it is loaded into the xylem where it is transported upwards by mass flow in the transpiration stream. Then, the unloading from the xylem vessels occurs following the concentration gradients generated in the growing tissues [4]. In fruit trees, it has been 
observed that rootstocks can supply higher quantities of mineral nutrients to the shoots by increasing the concentration of these elements in the xylem sap and/or enhancing the transpiration rate [5], but no information is available for grafted tomato plants.

Several reports provide evidence that rootstocks increase $\mathrm{NO}_{3}{ }^{-}$uptake in tomato plants $[2,6]$, but most studies have been conducted to test the effects under salinity stress conditions [7-9]. However, these studies do not address the concentration of $\mathrm{NO}_{3}{ }^{-}$in the xylem sap which has been shown to change in cucumber (Cucumis sativus) plants exposed to different root-zone temperatures [10], watermelon (Citrullus lanatus) plants grafted onto different rootstocks [11], or melon (Cucumis melo) plants grafted onto vigorous rootstocks [12]. Albacete et al. [13] report that various Solanum lycopersicum $\times$ Solanum cheesmaniae recombinant inbred lines with contrasting size-controlling characteristics affect the $\mathrm{K}^{+}$levels in the xylem sap, but they do not provide information on the content of $\mathrm{NO}_{3}{ }^{-}$.

In terms of the transport through the stem, rootstocks can affect the delivery of nutrients to the shoots by altering the transpiration rate. The transpiration flux through the stem is controlled by gradients in the stem water potential $\left(\Psi_{\mathrm{w}}\right)$. Due to the restrictions imposed by the graft union or at the root level, rootstocks can affect the stem water potential [14]. To a lesser extent, the water potential in the stem can be modified by changes in the osmotic potential of the xylem sap through changes in the concentration of ions, mainly potassium and nitrate, thus altering the transport capacity in the xylem $[15,16]$.

Ultimately, the water flow through the xylem depends upon the stem hydraulic conductance $\left(\mathrm{k}_{\mathrm{s}}, \mathrm{kg} \mathrm{H}_{2} \mathrm{O} \mathrm{m}^{-1} \mathrm{~s}^{-1} \mathrm{MPa}^{-1}\right)$. This corresponds to the flux of water $\left(\mathrm{F}, \mathrm{kg} \mathrm{s}^{-1}\right)$ through the stem cross-section area $\left(\mathrm{A}_{\mathrm{s}}, \mathrm{m}^{2}\right)$ for a given pressure difference $(\triangle \mathrm{P}, \mathrm{MPa})$ and normalized by the length of the path $(\mathrm{L}, \mathrm{m})[17]$ as in the following equation:

$$
\mathrm{k}_{\mathrm{s}}=\mathrm{F} /\left(\mathrm{A}_{\mathrm{s}} \times(\Delta \mathrm{P} / \mathrm{L})\right)
$$

Anatomically, it can be affected by the number of xylem vessels, their diameter, and the capacity of plants to modulate stem $\Psi_{\mathrm{w}}$ along the water path. Theoretically, the diameter of the vessels is more important than the number of vessels in determining the hydraulic conductance due to the relevance given in the Poiseuille-Hagen equation:

$$
\mathrm{k}_{\mathrm{h}}=(\pi \cdot \rho / 128 \eta) \sum_{i=1}^{n}\left(d_{i}^{4}\right)
$$

where $\mathrm{k}_{\mathrm{h}}$ is the theoretical hydraulic conductance $\left(\mathrm{kg} \mathrm{m} \mathrm{MPa}^{-1} \mathrm{~s}^{-1}\right), d$ is the radius of the vessel (m), $\rho$ is water density $\left(\mathrm{kg} \mathrm{m}^{-3}\right)$, and $\eta$ water viscosity (MPa s) [18]. Therefore, it is expected that those rootstock genotypes with larger vessels have an enhanced capacity to deliver water and nutrients to the shoot. A study of tomato rootstocks showed variations in both the number and diameter of vessels [19]. The limited importance of the number of xylem vessels in controlling the water supply to the shoots is supported by the data presented by Edelstein et al. [20], who evaluated 22 candidate genotypes to work as rootstocks for melon plants, showing no relation between vessel number and plant growth rate. On the contrary, rootstock vessel diameter has been positively correlated to growth vigor in peach trees [21]. Another piece of evidence of the importance of xylem vessel size in the capacity for xylem transport was provided in a study of the susceptibility of tomato genotypes to blossom-end rot which corresponds to a calcium deficiency explained by a limited water supply to the fruit. In this study, it was concluded that those genotypes with smaller xylem vessels are more susceptible to blossom-end rot because of a reduction in the transport capacity [22]. Even more, it has been shown in a study with potato (i.e., Solanum tuberosum) that different varieties have the ability to modulate vessel size and shape depending on the environmental conditions [23]. This implies that differences exist among varieties to supply water (and nutrients) depending on the plant's growth rate.

Based on this information, the present study aimed to assess xylem nitrate transport capacity in tomato plants grafted onto a vigorous rootstock. This research was conducted under the hypothesis that the transport rate is modulated by the plant's growth rate through changes in $\mathrm{NO}_{3}{ }^{-}$concentration 
in the stem xylem sap. The analysis was based on the concentration of $\mathrm{NO}_{3}{ }^{-}$in the xylem sap, the actual xylem hydraulic conductance, and the anatomical characteristics (i.e., vessel number and diameter) in plants grafted onto a vigorous rootstock in comparison to non-grafted and self-grafted plants.

\section{Materials and Methods}

The capacity for $\mathrm{NO}_{3}{ }^{-}$transport was evaluated in grafted tomato plants by measuring water uptake, stem hydraulic conductance, xylem vessel density and diameter, and xylem sap $\mathrm{NO}_{3}{ }^{-}$content. A growth chamber experiment replicated twice was carried out according to the following specifications.

\subsection{Plant Material and Growth Conditions}

Tomato seeds (Solanum lycopersicum L. cv. Attiya (AT), Rijk Zwan, De Lier, the Netherlands) and a vigorous interspecific hybrid (S. lycopersicum $\times$ S. habrochaites cv. Kaiser (KA), Rijk Zwan, De Lier, the Netherlands) were germinated in plastic trays containing $90 \%$ peat and $10 \%$ perlite. Trays were placed in a growth chamber under constant $25^{\circ} \mathrm{C}$ air temperature. Once seedling stems reached a diameter of $2 \mathrm{~mm}$, the following grafting treatments were prepared: a control consisting in non-grafted plants (AT), self-grafted plants (AT-AT), and grafted plants (AT-KA). Plants were grafted by cutting the stems at a $45^{\circ}$ angle and joining them using silicone clips. Immediately after, plants were left for two days in a growth chamber at $25{ }^{\circ} \mathrm{C}, 95 \%$ relative humidity, and light intensity below $20 \mu \mathrm{mol} \mathrm{m}^{-2} \mathrm{~s}^{-1}$. Later, the light intensity was increased to $200 \mu \mathrm{mol} \mathrm{m} \mathrm{m}^{-2} \mathrm{~s}^{-1}$ until callus formation and plants showed full recovery with no wilted leaves which was verified nine days later. After callus formation, and right before transplanting into the experimental conditions, eight plants of each grafting treatment were freshly weighed and dry weight (DW) was determined after oven drying at $55{ }^{\circ} \mathrm{C}$ until constant weight. At transplant, sixteen plants of each grafting treatment were grown hydroponically by placing individual plants in $1 \mathrm{~L}$ containers sealed with plastic to avoid direct evaporation. The number of containers was split in one of the following light treatments: $400 \mu \mathrm{mol} \mathrm{PAR} \mathrm{m}{ }^{-2} \mathrm{~s}^{-1}$ or $800 \mu \mathrm{mol}$ PAR $\mathrm{m}^{-2} \mathrm{~s}^{-1}$. Each light level was achieved using dimmable LED lamps (model LightDNA, Valoya, Finland). The photoperiod was $10 \mathrm{~h}$, and the air temperature corresponded to $25 / 18{ }^{\circ} \mathrm{C}$ day/night. Plants were distributed in a completely randomized design within each light treatment. Each container

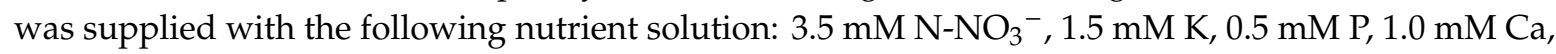
$0.5 \mathrm{mM} \mathrm{Mg}, 0.5 \mathrm{mM} \mathrm{S}, 45 \mu \mathrm{M}$ Fe-EDDHA, $40 \mu \mathrm{M}$ B, $1.0 \mu \mathrm{M}$ Mn, $0.2 \mu \mathrm{M}$ Zn, $0.1 \mu \mathrm{M} \mathrm{Cu}$, and $0.3 \mu \mathrm{M}$ Mo. The $\mathrm{pH}$ was adjusted at 5.8 using phosphoric acid. The solution was continuously aerated by an air

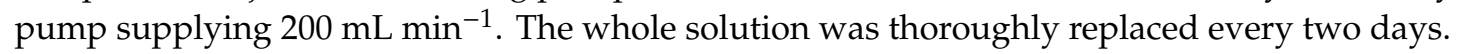

\subsection{Measurements}

Plants were grown for 14 days under the conditions described above, and the following measurements were carried out during the experiments.

\subsubsection{Plant Water Uptake}

Water uptake was measured daily by weighing each container individually before the lights turned on and after the lights turned off. The results presented below correspond to those measurements undertaken on the last day of the experiments and normalized by the plants' DW.

\subsubsection{Plant Growth Rate and RGR Calculations}

At the end of the growth period, each plant was harvested, and their fresh weight was recorded. Later, roots and shoots of four plants per grafting $\times$ light combination were separately placed in paper bags for DW determination after oven drying at $55^{\circ} \mathrm{C}$ for $72 \mathrm{~h}$. Shoot $\mathrm{N}$ concentration was determined in the dry samples by Kjeldahl distillation. 
The relative growth rate (RGR, $\mathrm{g} \mathrm{g}^{-1} \mathrm{~d}^{-1}$ ) was determined as the difference between the DW before transplant $\left(\mathrm{DW}_{1}, \mathrm{~g}\right)$ and the DW after harvest $\left(\mathrm{DW}_{2}\right)$ divided by the time of the experiment $(\mathrm{t})$, as in the following equation:

$$
\mathrm{RGR}=\left(\ln \left(\mathrm{DW}_{2}\right)-\ln \left(\mathrm{DW}_{1}\right)\right) / \mathrm{t}
$$

\subsubsection{Xylem Sap $\mathrm{NO}_{3}{ }^{-}$Content}

The remaining four plants of each grafting $\times$ light combination were used to extract xylem sap content and determine its $\mathrm{NO}_{3}{ }^{-}$concentration. Seven-cm long stem sections, including rootstock and scion in AT-AT and AT-KA, were cut underwater and connected to a pump pushing the xylem content with a $10 \mathrm{mM} \mathrm{KCl}$ solution at $0.02 \mathrm{MPa}$ until a volume of $1 \mathrm{~mL}$ was obtained. Then, $\mathrm{NO}_{3}{ }^{-}$content was determined by ion chromatography (model Dionex Aquion, Thermo Scientific, USA) using a $30 \mathrm{mM}$ $\mathrm{KOH}$ eluent solution injected at a $1 \mathrm{~mL} \mathrm{~min}^{-1}$ flow rate. The chromatograph was equipped with an anion pre-column (Dionex IonPac AG11-HC, $4 \mathrm{~mm}$ ) and a separator column (Dionex IonPac AS11-HC, $4 \mathrm{~mm}$ ) coupled with a self-regenerating suppressor (AERS 500, $4 \mathrm{~mm}$ ). The values obtained were corrected by a dilution factor obtained from the calculated xylem volume in the stem segments after the vessel number and diameter were determined.

\subsubsection{Stem Hydraulic Conductance $\left(\mathrm{k}_{\mathrm{s}}\right)$}

After the xylem content was collected, the same stem segments were used to determine stem hydraulic conductance $\left(\mathrm{k}_{\mathrm{s}}\right)$ following the flow rate method described by Pérez-Donoso et al. [24]. Briefly, stem segments were connected to a pump supplying a $10 \mathrm{mM} \mathrm{KCl}$ solution at $0.04,0.06$, and $0.08 \mathrm{MPa}$. Each pressure was maintained for five minutes, and the amount of water passing through the stems was weighed by an electronic balance connected to a computer. Then, stem hydraulic conductance $\left(\mathrm{k}_{\mathrm{s}}, \mathrm{kg} \mathrm{H}_{2} \mathrm{O} \mathrm{m}^{-1} \mathrm{~s}^{-1} \mathrm{MPa}^{-1}\right)$ was determined by plotting water flux $\left(\mathrm{F}, \mathrm{kg} \mathrm{s}^{-1}\right)$ at each pressure $(\mathrm{P}, \mathrm{MPa})$ and by determining the slope of the line. The calculation was corrected by the stem cross-section area $\left(\mathrm{A}_{\mathrm{s}}, \mathrm{m}^{2}\right)$ and the length of the stem section $(\mathrm{L}, \mathrm{m})$ as in Equation (1).

\subsubsection{Nitrate Transport Rate}

Plant $\mathrm{NO}_{3}{ }^{-}$transport rate was calculated by multiplying the concentration of $\mathrm{NO}_{3}{ }^{-}$in the xylem sap times the water uptake rate. The results are presented as per plant and also normalized by the DW.

\subsubsection{Theoretical Hydraulic Conductance $\left(\mathrm{k}_{\mathrm{h}}\right)$ Calculation}

The number of xylem vessels and their corresponding diameter were measured on the stems after $\mathrm{k}_{\mathrm{s}}$ determination. Samples were fixed in formol acetic alcohol for 24 hours and then dehydrated using tertiary butyl alcohol. Samples were included in paraffin once completely dehydrated and placed in an oven at $58{ }^{\circ} \mathrm{C}$. Twenty- $\mu \mathrm{m}$ thick cross-sections were collected $5 \mathrm{~mm}$ below and $5 \mathrm{~mm}$ above the joint section as well as from the joint section itself using a hand microtome. The cross-sections were dyed with a modified safranin and fast green protocol [25]. Finally, the cross-section cuts were placed on glass slides, covered with coverslips, and sealed with chemical glue for microscope observation

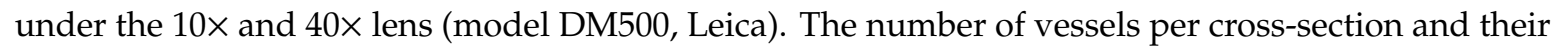
diameter were determined using the ImageJ software [26] in three technical replicates per sample. Then, the theoretical hydraulic conductance $\left(\mathrm{k}_{\mathrm{h}} ; \mathrm{kg} \mathrm{m} \mathrm{MPa}^{-1} \mathrm{~s}^{-1}\right)$ was calculated using the Poiseuille-Hagen equation (Equation (2)).

\subsection{Statistical Analysis}

Data from both experiments were pooled together, and differences in plant water uptake (measured on the last day of the experiment), xylem sap $\mathrm{NO}_{3}{ }^{-}$content, hydraulic conductance, vessel number, vessel diameter, theoretical hydraulic conductance, and nitrate transport rates were analyzed by two-way ANOVA with grafting and light as the main effects. Mean separation was carried out 
by Tukey's test. Pearson's correlation analysis was carried out to determine the significance of the correlation between the traits analyzed. All analyses were conducted using " $R$ " software [27] through the InfoStat console [28].

\section{Results}

The grafting treatment (AT-KA) increased biomass accumulation $(p<0.0033)$ in comparison to the control (ungrafted plants) and self-grafted treatments (Table 1 ). No differences in shoot $\mathrm{N}$ concentration were found among grafting treatments $(p<0.2144)$, but light level significantly reduced it $(p<0.0001)$.

Table 1. Plant dry weight and shoot $N$ concentration for non-grafted (AT), self-grafted (AT-AT) and

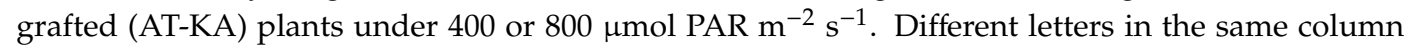
denote significant differences $(p<0.05)$.

\begin{tabular}{|c|c|c|c|c|}
\hline \multirow[b]{2}{*}{ Treatment } & \multicolumn{2}{|c|}{$400 \mu \mathrm{mol} \mathrm{m} \mathrm{m}^{-2} \mathrm{~s}^{-1}$} & \multicolumn{2}{|c|}{$800 \mu \mathrm{mol} \mathrm{m} \mathrm{m}^{-2} \mathrm{~s}^{-1}$} \\
\hline & $\begin{array}{l}\text { Plant Dry } \\
\text { Weight (g) }\end{array}$ & $\begin{array}{c}\text { N Content } \\
\left(\mathrm{mg} \mathrm{N} \mathrm{g}^{-1} \mathrm{DW}\right)\end{array}$ & $\begin{array}{c}\text { Plant Dry } \\
\text { Weight (g) }\end{array}$ & $\begin{array}{c}\text { N Content } \\
\left(\mathrm{mg} \mathrm{N} \mathrm{g}^{-1} \mathrm{DW}\right)\end{array}$ \\
\hline AT & $0.82 \pm 0.05 b$ & $46.8 \pm 1.7 \mathrm{a}$ & $1.69 \pm 0.24 \mathrm{ab}$ & $39.6 \pm 3.9 a$ \\
\hline AT-AT & $0.77 \pm 0.05 b$ & $42.5 \pm 2.2 \mathrm{a}$ & $1.56 \pm 0.22 b$ & $36.3 \pm 1.3 \mathrm{a}$ \\
\hline AT-KA & $1.11 \pm 0.13 \mathrm{a}$ & $45.6 \pm 2.1 \mathrm{a}$ & $2.32 \pm 0.18 \mathrm{a}$ & $33.7 \pm 2.1 \mathrm{a}$ \\
\hline
\end{tabular}

The growth rate of AT-KA was higher $(p<0.0049)$ than that of the control (AT) or AT-AT with average values of $0.1342 \pm 0.0053$ and $0.1151 \pm 0.0069 \mathrm{~g} \mathrm{~g}^{-1} \mathrm{~d}^{-1}$, respectively. Increasing the light from 400 to $800 \mu \mathrm{mol} \mathrm{PAR} \mathrm{m} \mathrm{m}^{-2} \mathrm{~s}^{-1}$, enhanced RGR by $37 \%(p<0.0001)$, from $0.1027 \pm 0.0034$ to $0.1414 \pm 0.0042 \mathrm{~g} \mathrm{~g}^{-1} \mathrm{~d}^{-1}$.

The water uptake rate was similar among grafting treatments $(p<0.4539)$ (Figure 1$)$, but a significant reduction $(p<0.0016)$ was evidenced with increasing light level.

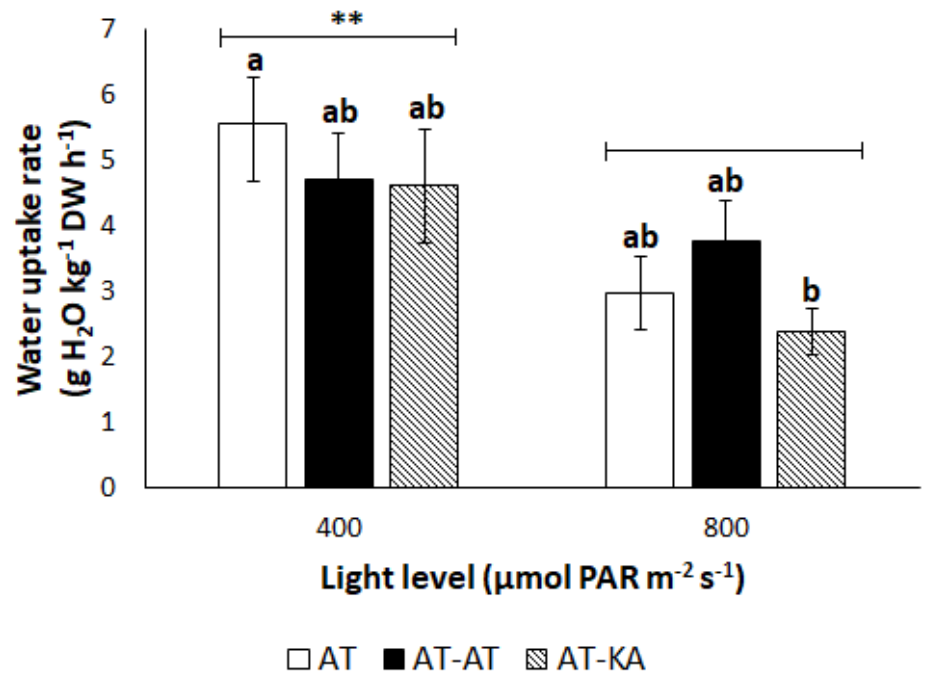

Figure 1. Water uptake rates under $400 \mu \mathrm{mol} \mathrm{PAR} \mathrm{m} \mathrm{m}^{-2} \mathrm{~s}^{-1}$ or $800 \mu \mathrm{mol} \mathrm{PAR} \mathrm{m} \mathrm{m}^{-2} \mathrm{~s}^{-1}$ for the non-grafted (AT), self-grafted (AT-AT), and grafted (AT-KA) treatments. Bars represent mean $\pm \mathrm{SE}$ of sixteen replicates. Different letters on top of the bars denote significant differences $(p<0.05)$ among grafting $\times$ light treatments. Asterisks on top of the light levels represent significant differences $\left({ }^{* *} p<0.01\right)$ for the light treatment.

No differences among the grafting treatments $(p<0.1324)$ were found for the $\mathrm{NO}_{3}{ }^{-}$content in the xylem sap (Figure 2). However, doubling the light level increased the $\mathrm{NO}_{3}{ }^{-}$content by 2.36 fold $(p<0.0001)$, from $7.61 \mathrm{mM}$ to $17.96 \mathrm{mM}$. 


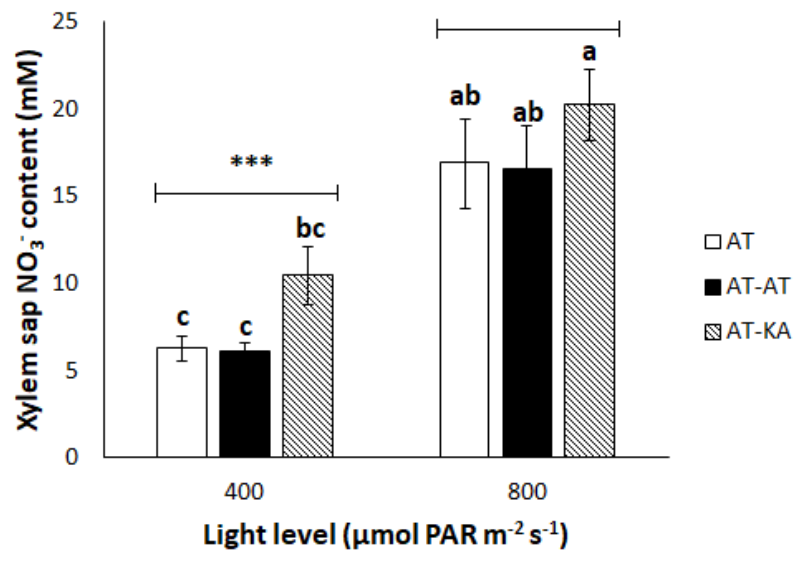

Figure 2. Nitrate content in the xylem sap of plants exposed to $400 \mu \mathrm{mol} \mathrm{PAR} \mathrm{m}{ }^{-2} \mathrm{~s}^{-1}$ or $800 \mu \mathrm{mol}$ PAR $\mathrm{m}^{-2} \mathrm{~s}^{-1}$. Bars represent mean $\pm \mathrm{SE}$ of eight replicates. Different letters on top of the bars denote significant differences $(p<0.05)$ among grafting $\times$ light treatments. Asterisks on top of light levels represent significant differences $(* * *<0.0001)$ for the light treatments.

The self-grafted treatment (AT-AT) showed a higher number of vessels $(p<0.0001)$ below the graft union in comparison to the control (non-grafted plants) (Table 2). However, the number of vessels $(p<0.5326)$ and their diameter $(p<0.7891)$, measured above the graft union, were similar in the self-grafted (AT-AT) and grafted (AT-KA) plants to that found in the non-grafted treatment. The highest vessel density was found in the stem sections of the rootstock (Table 2, Figure 3). Mean vessel diameter was also larger in the rootstock $(p<0.0248)$ which resulted in a one-order of magnitude higher $k_{h}$ values $(p<0.0390)$ in this treatment than in the non-grafted and self-grafted treatments. However, the actual values measured with the flow rate method indicate that AT-KA had a significantly lower hydraulic conductance $\left(\mathrm{k}_{\mathrm{s}}\right)$ than the other treatments $(p<0.0497)$ (Table 2$)$.

Table 2. Vessel number and vessel diameter measured below the graft union, calculated hydraulic conductance $\left(k_{h}\right)$ for the segment below the graft union, and stem hydraulic conductance $\left(k_{s}\right)$ measured in stem sections including rootstock, graft union, and scion portions. Values represent mean \pm SE of eight replicates. Different letters in the same column denote significant differences $(p<0.05)$ among grafting treatments.

\begin{tabular}{|c|c|c|c|c|}
\hline Treatment & $\begin{array}{l}\text { Vessel Number } \\
\left(\mathbf{N}^{\circ} \mathbf{m m}^{-2}\right)\end{array}$ & $\begin{array}{c}\text { Mean Vessel } \\
\text { Diameter }(\mu \mathrm{m})\end{array}$ & $\begin{array}{c}\mathrm{k}_{\mathrm{h}} \\
\left(\mathrm{kg} \mathrm{m} \mathrm{MPa}^{-1} \mathrm{~s}^{-1}\right)\end{array}$ & $\begin{array}{c}\mathrm{k}_{\mathrm{s}} \\
\left(\mathrm{kg} \mathrm{MPa}^{-1} \mathrm{~m}^{-1} \mathrm{~s}^{-1}\right)\end{array}$ \\
\hline AT & $23.5 \pm 1.65 c$ & $62.04 \pm 10.14 \mathrm{ab}$ & $5.8 \times 10^{-7} \mathrm{~b}$ & $0.560 \pm 0.213 \mathrm{a}$ \\
\hline AT-AT & $45.5 \pm 0.86 b$ & $54.90 \pm 7.46 \mathrm{~b}$ & $6.8 \times 10^{-7} \mathrm{~b}$ & $0.207 \pm 0.048 b$ \\
\hline AT-KA & $76.2 \pm 4.78 \mathrm{a}$ & $79.31 \pm 14.44 \mathrm{a}$ & $6.9 \times 10^{-6} \mathrm{a}$ & $0.090 \pm 0.025 c$ \\
\hline
\end{tabular}

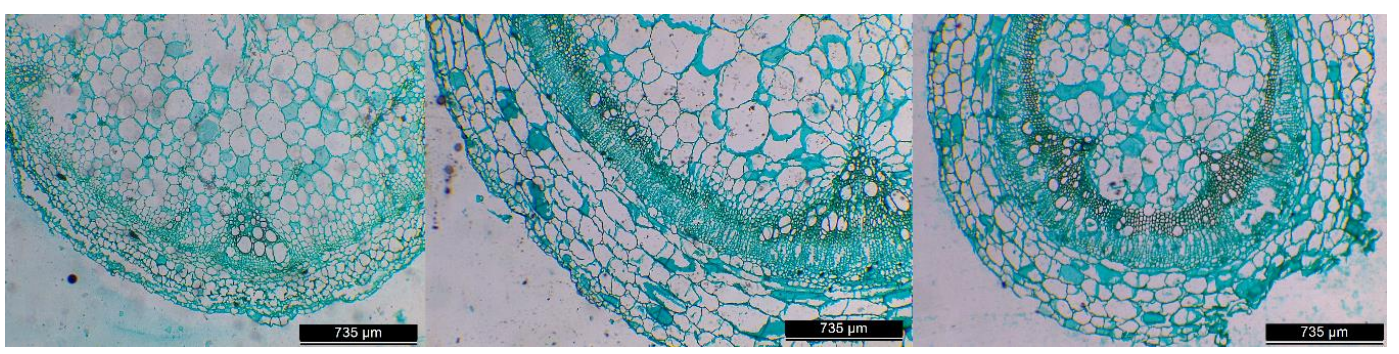

Figure 3. Stem cross-sections of AT (left), AT-AT (middle), and AT-KA (right). The pictures in AT-AT and AT-KA correspond to the rootstock section, taken below the graft union. 
The nitrate transport rate through the xylem was similar for all grafting treatments, either expressed on a plant $(p<0.0896)$ or DW basis $(p<0.9775)$. The average value for the $\mathrm{NO}_{3}{ }^{-}$transport rate was $49.43 \pm 14.44 \mu \mathrm{mol} \mathrm{NO}{ }^{-} \mathrm{g}^{-1} \mathrm{DW} \mathrm{h}^{-1}$ (Figure 4). Doubling the light level increased the $\mathrm{NO}_{3}{ }^{-}$ transport rate $(p<0.0001)$ in each grafting treatment.

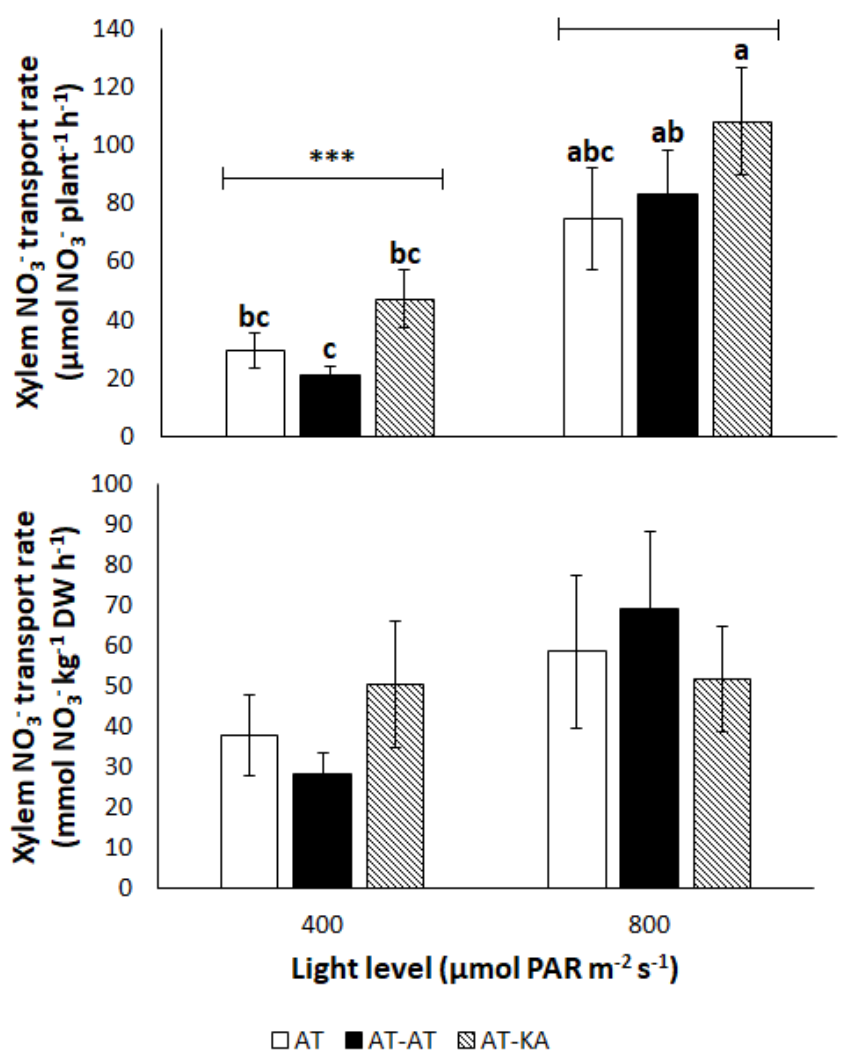

Figure 4. Nitrate transport rate in the xylem, expressed on a plant (top) or DW (bottom) basis, of

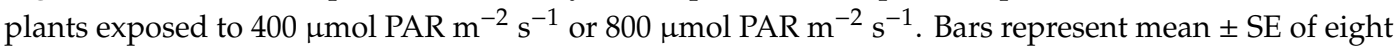
replicates. Different letters on top of the bars denote significant differences $(p<0.05)$ among grafting $\times$ light treatments. Asterisks on top of the light levels represent significant differences $\left({ }^{* * *} p<0.0001\right)$ among light treatments.

Nitrate content in the xylem sap presents a significant positive relationship with the plant's growth rate (Table 3). No significant relation between vessel diameter and $\mathrm{NO}_{3}{ }^{-}$transport rate was found.

Table 3. Pearson's coefficients and significance levels (n.s.: not significant; ${ }^{*} p<0.05 ;{ }^{* *} p<0.01$; *** $p<0.0001)$ for the correlation between each trait. WU: water uptake rate; N_T: nitrate transport rate; N_Xyl: nitrate content in the xylem sap; Ves_D: vessel diameter; Ves_N: vessel number; RGR.

\begin{tabular}{ccccccc}
\hline & WU & N_T & N_Xyl & Ves_D & Ves_N & RGR \\
\hline WU & - & $0.53^{* * *}$ & -0.10 n.s. & -0.03 n.s. & -0.14 n.s. & $-0.40^{* *}$ \\
N_T & $0.53^{* * *}$ & - & $0.72^{* * *}$ & 0.16 n.s. & 0.03 n.s. & 0.11 n.s. \\
N_Xyl & -0.10 n.s. & $0.72^{* * *}$ & - & 0.19 n.s. & 0.20 n.s. & $0.46^{* *}$ \\
Ves_D & -0.03 n.s. & 0.16 n.s. & 0.19 n.s. & - & $0.33^{*}$ & 0.25 n.s. \\
Ves_N & -0.14 n.s. & 0.03 n.s. & 0.20 n.s. & $0.33^{*}$ & - & 0.26 n.s. \\
RGR & $-0.40^{* *}$ & 0.11 n.s. & $0.46^{* *}$ & 0.25 n.s. & 0.26 n.s. & - \\
\hline
\end{tabular}




\section{Discussion}

\subsection{Nitrate Content in the Xylem Sap}

Following the uptake of $\mathrm{NO}_{3}{ }^{-}$in the roots (i.e. crossing the root endodermis), it is loaded into the xylem to be transported to the shoot. The regulation of xylem loading depends on the expression patterns of various $\mathrm{NO}_{3}{ }^{-}$transporters which are regulated by feedback mechanisms based on the accumulation of $\mathrm{NO}_{3}{ }^{-}$and/or $\mathrm{N}$-containing compounds transported from the shoot [29]. In a previous study, we showed that Kaiser has an enhanced root $\mathrm{NO}_{3}{ }^{-}$uptake activity in comparison to the roots of Attiya [2]; therefore, it was expected that $\mathrm{NO}_{3}{ }^{-}$concentration in the xylem would be higher. The results in the present study showed that the rootstock did not influence $\mathrm{NO}_{3}{ }^{-}$content in the xylem sap of the tomato plants, but environmental conditions leading to different growth rates modified its content. These findings are supported by the data provided by Orieux et al. [30], who showed that $\mathrm{NO}_{3}{ }^{-}$ content in the xylem sap of Brassica napus increases when plants enhance their biomass accumulation rate. On the other hand, the results presented by Galleguillos-Cedillo et al. [31] show a stable $\mathrm{NO}_{3}{ }^{-}$ content in the xylem sap of tomato plants subjected to electrical conductivity values ranging from 2.2 to $12 \mathrm{dS} \mathrm{m} \mathrm{m}^{-1}$, EC values that significantly affected the transpiration and, therefore, growth rate.

The reduction in water transport was larger than the increase in xylem $\mathrm{NO}_{3}{ }^{-}$concentration across light levels, leading to a decrease in shoot $\mathrm{N}$ content in plants subjected to higher radiation (Table 1). Changes in the stoichiometry of mineral elements in plant tissue have been reported in plants subjected to different types of stress [32], but in the present experiments, the light conditions applied do not imply stress for tomato plants [33]. With regards to the effects of rootstock genotypes on shoot $\mathrm{N}$ concentration, contradictory results have been reported for interspecific rootstocks of S. lycopesicum $\times S$. habrochaites. Most of the reports conclude that genotypes such as Beaufort, Mutifort or He-Man increase the concentration of $\mathrm{N}$ in the shoot [34-36]. Another common rootstock is Maxifort which has shown genotype-specific responses to shoot $\mathrm{N}$ concentration. When used with tomato cv. Money Maker as scion, it does not affect shoot $\mathrm{N}$ concentration [36], while the effect on cv. Primadonna as scion was to promote $\mathrm{N}$ content in the shoot biomass, in comparison to non-grafted plants [35].

\subsection{Water Transport Rate}

Increasing the light level enhanced shoot biomass, but this is accompanied by a decrease in the water uptake rate per gram of plant dry biomass. Tomato plants exposed to different light levels exhibit an increase in shoot growth at the highest radiation but reduce the relative allocation of biomass to the leaves [37]. This, in turn, results in a reduction of the leaf area per gram of plant biomass (the leaf area ratio) and the amount of leaf area per unit leaf mass (the specific leaf area) [37]. In the present experiment, leaf area was not measured, but the water uptake results are in agreement with the report by De Groot et al. [37]. An increase in the net photosynthetic $\mathrm{CO}_{2}$ assimilation rate is expected from 400 to $800 \mu \mathrm{mol}$ PAR $\mathrm{m}^{-2} \mathrm{~s}^{-1}$ [38] but accompanied by a higher allocation of resources to the stems and roots [37]. Since a higher proportion of plant biomass is allocated to non-transpiring organs, a reduction in the water uptake rate per gram of plant biomass is observed.

The process of grafting imposes a barrier for water movement as shown by the reduction in $\mathrm{k}_{\mathrm{s}}$ in the present study. After grafting, in the model plant Arabidopsis, the first anatomical change that occurs is the union between the scion and the rootstock, followed three days later by the phloem connection. It takes up to seven days for the xylem to be fully reconnected allowing an efficient water movement across the plant, but it can take longer in other species [39,40]. Nevertheless, this process of revascularization starts in the scion, thanks to the auxin polar transport from the apex to the wound site, and only after does the rootstock follows $[39,40]$. Considering the anatomical differences between Arabidopsis and tomato, the latter could take longer to reconnect the xylem after grafting which could explain lower $\mathrm{k}_{\mathrm{s}}$ in the AT-KA treatments, independently of having more and larger vessels. Fernandez-Garcia et al. [41] showed in their study that fully formed xylem vessels were present at the graft union 15 days after grafting by means of showing one xylem vessel. However, they did not 
check how many xylem vessels were actually functional at 15 days but explained their functionality by means of measuring the root hydraulic conductance which was stable after 15 days. To understand the proper revascularization of tomato grafts it is necessary to quantify the number of fully functional xylem vessels at the graft union for longer periods of time after grafting and look at both $\mathrm{k}_{\mathrm{s}}$ and root hydraulic conductance.

Based on the results from our study, we might assume that differences exist in the mechanisms supplying water (and N) to the aerial parts of the plant due to the restriction imposed by the grafting union to the water movement and that the supply of $\mathrm{N}$ to the shoot is similar in grafted and non-grafted plants. This difference is not related to the concentration of $\mathrm{NO}_{3}{ }^{-}$in the xylem sap, since it is similar in grafted and non-grafted plants. Similarly, the water uptake rate is equivalent between grafted and non-grafted plants, but the hydraulic conductance measured in the stem segments $\left(k_{s}\right)$ is much lower in the grafted plants, particularly in the AT-KA treatment. This is in opposition to the hydraulic conductance $\left(\mathrm{k}_{\mathrm{h}}\right)$ obtained with the Poiseuille-Hagen equation and the xylem conduit diameters measured in Kaiser and Attiya stem sections. The Ohm's law analogy indicates that this opposite tendency in the magnitude of the conductance $\left(\mathrm{k}_{\mathrm{h}}\right)$ below the graft union and that of the stem segment containing a portion of the rootstock and scion $\left(\mathrm{k}_{\mathrm{s}}\right)$ must be due to the higher resistance at the graft union. Accordingly, this hydraulic resistance is, in fact, higher in grafted (AT-KA) than in non-grafted plants. Furthermore, the anatomical differences among rootstock treatments that led to differences in $\mathrm{k}_{\mathrm{h}}$ may facilitate the generation of a water potential difference by reducing the tension of the water ( $\triangle \mathrm{P}$ in Equation (1)) on the rootstock side, allowing the maintenance of the transpiration rate across treatments. Alternatively, the generation of a water potential difference between rootstock and scion could be partially achieved by concentrating solutes in the xylem stream of the scion, for example, potassium and nitrate $[15,16,42]$, but this needs to be further examined.

\section{Conclusions}

Light modulates the growth rate of tomato plants cv. Attiya and affects the $\mathrm{NO}_{3}{ }^{-}$content in the xylem sap. Grafting onto the vigorous interspecific rootstock cv. Kaiser enhances plant biomass accumulation, but it does not alter xylem sap $\mathrm{NO}_{3}{ }^{-}$content or plant water uptake rate. The rootstock has a vascular system with larger vessels in a higher density than non-grafted plants, but the stem hydraulic conductance is lower. Overall, the transport rate of $\mathrm{NO}_{3}{ }^{-}$through the stem is not affected by the grafting treatment.

Author Contributions: Conceptualization, F.A. and A.G.P.-D.; methodology, F.A., A.G.P.-D., M.G. and Ú.S.; formal analysis, F.A., J.L.U. and M.M.; data curation, F.A.; writing-original draft preparation, F.A.; writing-review and editing, A.G.P.-D., M.M. and Ú.S.; project administration, F.A.; funding acquisition, F.A. All authors have read and agreed to the published version of the manuscript.

Funding: This research was funded by FONDECYT-CONICYT Chile, grant number 11160026.

Acknowledgments: The authors acknowledge the contribution of Raúl Martínez in data collection.

Conflicts of Interest: The authors declare no conflict of interest.

\section{References}

1. King, S.R.; Davis, A.R.; Zhang, X.; Crosby, K. Genetic breeding and selection of rootstocks for Solanaceae and Cucurbitaceae. Sci. Hortic. 2010, 127, 106-111. [CrossRef]

2. Albornoz, F.; Gebauer, M.; Ponce, C.; Cabeza, R. LeNRT1.1 improves nitrate uptake in grafted tomato plants under high nitrogen demand. Int. J. Mol. Sci. 2018, 19, 3921. [CrossRef] [PubMed]

3. Djidonou, D.; Zhao, X.; Brecht, J.K.; Cordasco, K.M. Influence of interspecific hybrid rootstocks on tomato growth, nutrient accumulation, yield, and fruit composition under greenhouse conditions. HortTechonology 2017, 27, 868-877. [CrossRef]

4. Marschner, P. Marschner's Mineral Nutrition of Higher Plants, 3rd ed.; Academic Press: San Diego, CA, USA, 2012; pp. 49-70. 
5. Grassi, G.; Millard, P.; Wendler, R.; Minotta, G.; Tagliavini, M. Measurements of xylem sap amino acid concentrations in conjunction with whole tree transpiration estimates spring $\mathrm{N}$ remobilization by cherry (Prunus avium L.) trees. Plant Cell Environ. 2002, 25, 1689-1699. [CrossRef]

6. Djidonou, D.; Lopiano, K.; Zhao, X.; Simonne, E.H.; Erickson, J.E.; Koch, K.E. Estimating nitrogen nutritional crop requirements of grafted tomatoes under field conditions. Sci. Hortic. 2015, 182, 18-26. [CrossRef]

7. Chen, G.; Fu, X.; Lips, H.; Sagi, M. Control of plant growth resides in the shoot, and not in the root, in reciprocal grafts of flacca and wild-type tomato (Lycopersicon esculentum), in the presence and absence of salinity stress. Plant Soil 2003, 256, 205-215. [CrossRef]

8. Sánchez-Rodríguez, E.; Leyva, R.; Constán-Aguilar, C.; Romero, L.; Ruíz, J.M. How does grafting affect the ionome of cherry tomato plants under water stress? Soil Sci. Plant Nutr. 2014, 60, 145-155. [CrossRef]

9. Asins, M.J.; Albacete, A.; Martínez-Andujar, C.; Pérez-Alfocea, F.; Dodd, I.C.; Carbonell, E.A.; Dieleman, J.A. Genetic analysis of rootstock-mediated nitrogen $(\mathrm{N})$ uptake and root-to-shoot signaling at contrasting $\mathrm{N}$ availabilities in tomato. Plant Sci. 2017, 263, 94-106. [CrossRef]

10. Choi, K.J.; Chung, G.C.; Ahn, S.J. Effect of root zone temperature on the mineral composition of xylem sap and plasma membrane $\mathrm{K}^{+}-\mathrm{Mg}^{++}$-ATPase activity of grafted-cucumber and -figleaf gourd root systems. Plant Cell Physiol. 1995, 36, 639-643. [CrossRef]

11. Yamasaki, A.; Yamashita, M.; Furuya, S. Mineral concentrations and cytokinin activity in the xylem exudate of grafted watermelons as affected by rootstocks and crop load. J. Japan. Soc. Hort. Sci. 1994, 62, 817-826. [CrossRef]

12. Salehi, R.; Kashi, A.; Lee, J.; Babalar, M.; Delshad, M.; Lee, S.; Huh, Y. Leaf gas exchange and mineral ion composition in xylem sap of Iranian melon affected by rootstocks and training methods. HortScience 2010, 45, 766-770. [CrossRef]

13. Albacete, A.; Martínez-Andújar, C.; Ghanem, M.E.; Acosta, M.; Sánchez-Bravo, J.; Asins, M.J.; Cuartero, J.; Lutts, S.; Dodd, I.C.; Pérez-Alfocea, F. Rootstock-mediated changes in xylem ionic and hormonal status are correlated with delayed leaf senescence, and increased leaf area and crop productivity in salinized tomato. Plant Cell Environ. 2009, 32, 928-938. [CrossRef]

14. Weibel, A.; Johnson, R.S.; DeJong, T.M. Comparative vegetative growth responses of two peach cultivars grown on size-controlling versus standard rootstocks. J. Am. Soc. Hortic. Sci. 2003, 128, 463-471. [CrossRef]

15. Sellin, A.; Ounapuu, E.; Karusion, A.; Oren, R. Experimental evidence supporting the concept of light-mediated modulation of stem hydraulic conductance. Tree Physiol. 2010, 30, 1528-1535. [CrossRef]

16. Ragel, P.; Raddatz, N.; Leidi, E.O.; Quintero, F.J.; Pardo, J.M. Regulation of K+ nutrition in plants. Front. Plant Sci. 2019, 10. [CrossRef]

17. Melcher, P.J.; Holbrook, N.M.; Burns, M.J.; Zwieniecki, M.A.; Cobb, A.R.; Brodribb, T.J.; Choat, B.; Sack, L. Measurements of stem xylem hydraulic conductivity in the laboratory and field. Methods Ecol. Evol. 2012, 3, 685-694. [CrossRef]

18. Tombesi, S.; Johnson, R.S.; Day, K.R.; DeJong, T.M. Relationship between xylem vessel characteristics, calculated axial hydraulic conductance and size-controlling capacity of peach rootstocks. Ann. Bot. 2010, 105, 327-331. [CrossRef]

19. Sory, A.; Nieto-Angel, R.; Rodríguez-Pérez, J.E.; Barrientos-Priego, A.F.; Ibañez-Castillo, L.A.; Romabchik, E.; Núñez-Colín, C.A. Variación anatómica del xilema en tallo de cultivares de tomate injertados en un tipo criollo. Rev. Chapingo Ser. Hortic. 2010, 16, 67-76.

20. Edelstein, M.; Burger, Y.; Horev, C.; Porat, A.; Meir, A.; Cohen, R. Assessing the effect of genetic and anatomic variation of Cucurbita rootstocks on vigor, survival and yield of grafted melons. J. Hortic. Sci. Biotechnol. 2004, 79, 370-374. [CrossRef]

21. Belda, R.M.; Fenlon, J.S.; Ho, L.C. Salinity effects on the xylem vessels in tomato fruit among cultivars with different susceptibilities to blossom-end rot. J. Hort. Sci. 1996, 71, 173-179. [CrossRef]

22. Paul, S.; Das, M.K.; Baishya, P.; Ramteke, A.; Farooq, M.; Baroowa, B.; Sunkar, R.; Gogoi, N. Effect of high temperature on yield associated parameters and vascular bundle development in five potato cultivars. Sci. Hortic. 2017, 225, 134-140. [CrossRef]

23. Pérez-Donoso, A.; Greve, L.C.; Walton, J.H.; Shackel, K.A.; Labavitch, J.M. Xylella fastidiosa infection and ethylene exposure result in xylem and water movement disruption in grapevine shoots. Plant Physiol. 2007, 143, 1024-1036. [CrossRef] [PubMed]

24. Johansen, D.A. Plant Microtechnique, 1st ed.; McGraw-Hill: New York, NY, USA, 1940; pp. 65-94. 
25. Schneider, C.A.; Rasband, W.S.; Eliceiri, K.W. NIH Image to ImageJ: 25 years of image analysis. Nat. Methods 2012, 9, 671-675. [CrossRef]

26. R Development Core Team. R: A Language and Environment for Statistical Computing; R Foundation for Statistical Computing: Vienna, Austria, 2008.

27. Di Rienzo, J.A.; Casanoves, F.; Balzarini, M.G.; Gonzalez, L.; Tablada, M.; Robledo, C.W. InfoStat Version 2014; Grupo InfoStat, Universidad Nacional de Córdoba: Córdoba, Argentina, 2014.

28. Miller, A.J.; Shen, Q.; Xu, G. Freeways in the plant: Transporters for N, P and S and their regulation. Curr. Opin. Plant Biol. 2009, 12, 284-290. [CrossRef]

29. Orieux, C.; Demarest, G.; Decau, M.; Beauclair, P.; Bataille, M.; Le Deunff, E. Changes in ${ }^{15} \mathrm{NO}_{3}{ }^{-}$availability and transpiration rate are associated with a rapid diurnal adjustment of anion contents as well as ${ }^{15} \mathrm{~N}$ and water fluxes between the roots and shoots. Front. Plant Sci. 2018, 9, 1751. [CrossRef]

30. Galleguillos-Cedillo, V.M.; Urrestarazu, M.; Álvaro, J.E. Influence of salinity on transport of nitrates and potassium by means of the xylem sap content between roots and shoots in young tomato plants. J. Soil Sci. Plant Nutr. 2016, 16, 991-998.

31. Rivas-Ubach, A.; Sardans, J.; Pérez-Trujillo, M.; Estiarte, M.; Peñuelas, J. Strong relationship between elemental stoichiometry and metabolome in plants. Proc. Natl. Acad. Sci. USA 2012, 109, 4181-4186. [CrossRef]

32. Zgallaï, H.; Steppe, K.; Lemeur, R. Photosynthetic, physiological and biochemical responses of tomato plants to polyethylene glycol-induced water deficit. J. Integr. Plant Biol. 2005, 47, 1470-1478. [CrossRef]

33. Leonardi, C.; Giuffrida, F. Variation of plant growth and macronutrient uptake in grafted tomatoes and eggplants on three different rootstocks. Europ. J. Hort. Sci. 2006, 71, 97-101.

34. Savvas, D.; Öztekin, G.B.; Tepecik, M.; Ropokis, A.; Tüzel, Y.; Ntatsi, G.; Schwarz, D. Impact of grafting and rootstock on nutrient-to-water uptake ratios during the first month after planting of hydroponically grown tomato. J. Hort. Sci. Biotechnol. 2017, 92, 294-302. [CrossRef]

35. Djidonou, D.; Zhao, X.; Koch, K.E.; Zotarelli, L. Nitrogen accumulation and root distribution of grafted tomato plants as affected by nitrogen fertilization. HortScience 2019, 54, 1907-1914. [CrossRef]

36. Borgognone, D.; Colla, G.; Rouphael, Y.; Cardarelli, M.; Rea, E.; Schwarz, D. Effect of nitrogen form and nutrient solution $\mathrm{pH}$ on growth and mineral composition of self-grafted and grafted tomatoes. Sci. Hortic. 2013, 149, 61-69. [CrossRef]

37. De Groot, C.C.; Marcelis, L.F.M.; Van Den Boogaard, R.; Lambers, H. Growth and dry-mass partitioning in tomato as affected by phosphorus nutrition and light. Plant Cell Environ. 2001, 24, 1309-1317. [CrossRef]

38. Xiaoying, L.; Shirong, G.; Taotao, C.; Zhigang, X.; Tezuka, T. Regulation of the growth and photosynthesis of cherry tomato seedlings by different light irradiations of light emitting diodes (LED). African J. Biotechnol. 2012, 11, 6169-6177. [CrossRef]

39. Melnyk, C.W.; Schuster, C.; Leyser, O.; Meyerowitz, E.M. A developmental framework for graft formation and vascular reconnection in Arabidopsis thaliana. Curr. Biol. 2015, 25, 1306-1318. [CrossRef]

40. Melnyk, C.W. Plant grafting: Insights into tissue regeneration. Regeneration 2017, 4, 3-14. [CrossRef]

41. Fernandez-Garcia, N.; Carvajal, M.; Olmos, E. Graft union formation in tomato plants: Peroxidase and catalase involvement. Ann. Bot. 2004, 93, 53-60. [CrossRef]

42. Zwieniecki, M.; Melcher, P.J.; Holbrook, N.M. Hydrogel control of xylem hydraulic resistance in plants. Science 2001, 291, 1059-1062. [CrossRef]

(C) 2020 by the authors. Licensee MDPI, Basel, Switzerland. This article is an open access article distributed under the terms and conditions of the Creative Commons Attribution (CC BY) license (http://creativecommons.org/licenses/by/4.0/). 